\title{
PARENTS' PERCEPTION OF COMMUNICATION DISORDERS IN CHILDHOOD
}

\author{
Gabriela Stabel Wolff', Bárbara Niegia Garcia de Goulart²
}

\begin{abstract}
Objective: to acertain parents perception of the occurrence of and factors associated with speechlanguage and hearing disorders in early childhood. Methods: from interviews using a structured questionnaire, 75 parents of preschool children in southern Brazil were interviewed. The following variables were studied: gender, age, number of children and knowledge of the phonological disorders, such as age for language changes, results of hearing problems, behavior problems before speech therapy, what the deleterious habits can cause in children and knowledge of the speech therapy. Results: in case of suspicion of a speech-language disorder, 46 (61.3\%) of parents seek evaluation by speech-language therapist and $37(49.3 \%)$ by pediatricians. The higher the parents' educational level of the, more they tend to consider the age group between 4-5 years as the final age of phonological acquisition and overcoming of speech disorders related to language development $(p=0.005)$. The relevancy between parents' knowledge about baby's bottle and pacifier to their schooling was not statistically significant $(p=0.549)$. Conclusion: the parent's knowledge has converged with the recommendations in the present regarding the occurrence and comorbidities associated with hearing difficulties and acquisition and language development in early childhood.
\end{abstract}

Key words: speech; language and hearing sciences; communication; child health; child language; language development disorders; speech; speech disorders; hearing; hearing disorders; hearing loss.

\section{INTRODUCTION}

Phonoaudiological disorders can include changes in oral communication, in the writing, hearing, balance, orofacial motricity and deglutition that can occur singly or in associat. The early identification and effective treatment of such disorders help reduce the occurrence of comorbidities, since early specialized intervention can prevent the co-occurrence of voice, speech, hearing and language difficulties and of phonoaudiological disorders prevailing in the first decade of life ${ }^{2}$.

Itis important to consider that human communication has dimensions beyond the biological sphere. Itis a complex system that involves physi- cal expression, writing and verbal communication. Communication disorders potential repercussions in the person hinself or in his relatives are difficult to measure.

However, clinical praxis shows that these problems influence the person's relationship with the environment, or his self-image, and also his formal and informal learning.

Thus, considering the fact that parents are normally part of their children's development since the first days of their lives, they have, in principle, greater opportunity to identify potential phonoaudiological problems, prematurely especially those related to motricity and orofacial functions, oral language and hearing.

Speech Therapist, Specialist in Infant Speech Therapy (UFRGS).

2 Associate Professor, Universidade Federal do Rio Grande do Sul (UFRGS).

Paper developed at Universidade Federal do Rio Grande do Sul, Institutional and Social Psychology Department.

Corresponding author: bgoulart@ufrgs.br; gabi-wolff@hotmail.com

Suggested citation: Wolff GS, Goulart BNG. Parents' perception of communication disorders in childhood; Journal of Human Growth and Development 2013; 23(2): 177-183

Manuscript submitted Jul 16 2012, accepted for publication Dec 192012. 
This study's goal is to describe parents' perception of phonoaudiological problems in the early childhood of their childreen and their associated factors.

\section{METHODS}

A cross-sectional descriptive study of one of the parents or the caregiver of each of the 124 children attending three basic education schools in the metropolitan area of Porto Alegre, southern Brazil.
All the 124 parents or caregivers with had no childreen attending school normally and who don't have previous contact to speech therapy were eligible for the study. The criteria used for eliminating parents from this sample ware those who did not wish to participate or who did not attend the meeting where the study questionnaire was applied. This 75 parents were actually interviewed ( 75 children aged between 12 and 48 months).

The data related parents' perception of phonoaudiological problems were analyzed by means of interviews using a structured questionnaire with open and closed answers (annex A).

ANNEX A - Data gathering document

I - IDENTIFICATION

\author{
1 - Gender: (1) male $\quad$ (2) female \\ 2 - Age: \\ 3 - Education: \\ 4- Field of work: \\ 5 - How many children? \\ 6 - Children age?
}

\title{
II - KNOWLEDGE LEVEL
}

7 - Up to what age do you think it normal to for speech errors to occur in a child's speech?

8 - Around what age do you think children should begin to talk?

9 - What would you do if you suspected some delay in a child's speech delay?

10 - Give up to 5 possible speede-therapy options in chidhood.

10 - Since which age do you believe speech therapist action can influence the child?

11 - Have you ever looked for some support, evaluation, and/or some speech therapist guidance for your child? (1) yes (2) no

12 - Do you believe hearing is important for:
(1) learning how to talk
(2) communication
(3) the overall development of a child
(4) listening to music
(5) some other. speeity?

13 - A child with hearing problems can have:
(1) speech problems
(4) school problems
(7) none of the above
(2) language problems
(5) emotional problems
(8) some other. Which?
(3) voice problems
(6) behavior problems

14 - What kind of problems do you think the baby's bottle and the pacifier create for the child?

The following variables were checked: gender, age, number of children and knowledge of phonoaudiological disorders, expected age for language changes related to development, hearing problems, conduct in view of speech problem iden- tification, identification of debilitating habits and recognition of and potential repercussions for speech and orofacial motricity.

Interviewed parents' socio demographic characteristics are presented in Table 1. 
Table 1: Interviewed parents' socio-demographic characteristics

\begin{tabular}{|c|c|c|c|c|}
\hline Characteristics & & $\mathbf{N}$ & $\%$ & cumulative $\%$ \\
\hline \multirow{2}{*}{ Gender } & Female & 70 & 93.3 & 93.3 \\
\hline & Male & 5 & 6.7 & 100.0 \\
\hline \multirow{4}{*}{$\begin{array}{c}\text { Parents' age } \\
\text { (Median } 32 \text { years old) }\end{array}$} & $16-20$ & 5 & 6.6 & 15.0 \\
\hline & $21-30$ & 21 & 30.5 & 30.5 \\
\hline & $31-40$ & 41 & 59.4 & 89.9 \\
\hline & $41-49$ & 7 & 10.1 & 100.0 \\
\hline \multirow{8}{*}{ Level of education } & Full Elementary school & 21 & 28.0 & 28.0 \\
\hline & Incomplete Elementary School & 16 & 21.3 & 49.3 \\
\hline & Full High School & 6 & 8.0 & 57.3 \\
\hline & Incomplete High School & 3 & 4.0 & 61.3 \\
\hline & Full Graduation & 14 & 18.7 & 80.0 \\
\hline & Incomplete Graduation & 4 & 5.3 & 85.3 \\
\hline & Post-graduation/Specialization & 6 & 8.0 & 93.3 \\
\hline & Master's degree & 5 & 6.7 & 100.0 \\
\hline \multirow{13}{*}{ Field of work } & Education & 11 & 14.7 & 15.1 \\
\hline & Health & 12 & 16.0 & 31.5 \\
\hline & Legal & 5 & 6.7 & 38.4 \\
\hline & Administrative & 12 & 16.0 & 54.8 \\
\hline & Trade & 6 & 8.0 & 63.0 \\
\hline & Advertising and Public Relations & 4 & 5.3 & 68.5 \\
\hline & Export & 3 & 4.0 & 72.6 \\
\hline & Informatics & 2 & 2.7 & 75.3 \\
\hline & Tourism & 2 & 2.7 & 78.1 \\
\hline & House hold & 11 & 14.7 & 93.2 \\
\hline & Gastronomy & 1 & 1.3 & 94.5 \\
\hline & Public Security & 2 & 2.7 & 97.3 \\
\hline & Beauty & 2 & 2.7 & 100.0 \\
\hline \multirow{5}{*}{ Number of children } & 1 & 47 & 62.7 & 62.7 \\
\hline & 2 & 19 & 25.3 & 88.0 \\
\hline & 3 & 6 & 8.0 & 96.0 \\
\hline & 4 & 2 & 2.7 & 98.7 \\
\hline & 7 & 1 & 1.3 & 100.0 \\
\hline
\end{tabular}

Pearson's chi-squared test was used to check the link between qualifying variables. Asymmetric distribution variables were tested using Mann-Whitney Test. The significance level adopted was 5\%.

This study was analyzed and approved by the Research Ethics Committee under the Protocol of the institution of origin.

\section{RESULTS}

Data relating to parents' perception about expected age for speech changes, the age (in months) in which the child should begin to talk according to parents and their perception as to the best age for phonoaudiological intervention (if necessary) are presented in Table 2.

\footnotetext{
** You can select multiple choices.
} 
Table 2: Parents' perception about language development, hearing, kind of professional to look for in when of communication changes in childhood are suspectet and the effect of speech therapy intervention in early childhood, as well as the best moment for these, if necessary

Parents' perception (information level/knowledge)

Age limit considered normal for occurence of speech changes (years)

Age when the child should begin to say the first waningfel words (in months)

In case of suspicious of speech delay, which professional should I look for**

Minimal age at which parent/caregiver judges phonoaudiological intervention possible, if needed (years)

Effect of speech therapist's intervention in early childhood when parents observe communication disorders (classified by researchers by speech therapy field of work area)

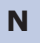

Speech therapist

Speech

Deglutition

\footnotetext{
* possibility of multiple alternatives.
}

The speech and language evaluation is made to check on the emotional and cognitive aspects of the child's development, which dray indicate the severity of the case, as well as the need of specialized guidance for the family and/or speech therapy ${ }^{3}$. In the literature it is mentioned that parents ex- pect for the spontaneous improvement of childhood communication disorders, especially when they are based on the comparison between the communicative abilities of their child and other children and also on the establishment of a parallel between intelligence and language difficulties.

** You dray make several. 
The findings of this study about parents' perception regarding a speech therapist's ability to intervbene in early childhood are consistent to the literature $2,3,7,8$, and itis possible to classify it didactically.

Nineteen $(25,3 \%)$ of the parents that answered the research had already contacted a speech therapist during the time of otoacoustic emission in the neonatal period.
Parents' perception about hearing, hearing health and pacifier and feeding bottle use and their relation with communication disorders are presented in Table 3. A positive association between parents' education and the age they judge to be right for speech changes had been noted $(p=0.005)$; that is, the higher the parents' educational level was, the more they tended to consider 4-5 years as the final age for language acquisition and the overcoming of speech changes related to language development.

Table 3: Parents' perception as to several aspects the relation between hearing and a child's health such as commorbidities asspociated with hearing deficits and with bad use of pacifier and feeding bottle

\begin{tabular}{|c|c|c|c|}
\hline Parents Perception about comorbidities & & $\mathbf{N}$ & $\%$ \\
\hline \multirow[b]{2}{*}{ Hearing heath importance in } & Overall. development of the child & 69 & 92.0 \\
\hline & Listening to music & 14 & 18.7 \\
\hline \multirow{6}{*}{ Comorbidities associated to with difficulties** } & Speech problems & 65 & 86.7 \\
\hline & Language changes & 48 & 64.0 \\
\hline & School difficulties & 58 & 77.3 \\
\hline & Social/behavior difficulties & 48 & 64.0 \\
\hline & Emotional difficulties & 47 & 62.7 \\
\hline & Voice Problems & 35 & 46.7 \\
\hline \multirow{8}{*}{$\begin{array}{c}\text { Consequences of bad use of pacifier } \\
\text { and feeding bottle }\end{array}$} & Dental problems & 47 & 62.7 \\
\hline & Speech problems & 36 & 48.0 \\
\hline & No problem at all & 9 & 12.0 \\
\hline & Listening to music & 14 & $18.7 * *$ \\
\hline & Emotional dependence & 8 & 10.7 \\
\hline & Breathing & 4 & 5.3 \\
\hline & Deglutition & 2 & 2.7 \\
\hline & No problems when used for a short period & 2 & 2.7 \\
\hline
\end{tabular}

On the relation between the number of children and what should be done in case of suspicious of speech delay, there was not significante difference ( $p=0.087)$, noravas there regards seeking or orientation and the age at speech therapy al witch, for parents $(p=0.149)$.

Noa is parents' knowledge could by active of pacifier and feeding bottle with their level of schooling significant ( $p=0.549)$.

\section{DISCUSSION}

Interviewed parents of the relationchip of wath age the child is supposed to speak correctly, as well as the speech therapist at field of expertise as regards hearing and speech in childhood. This is in line with other studies 1-5 and differs from others' conclusions 6,7, probably due to social differences and access to knowledge, especially that related to health care access among each study population. In general, parents identify four as the as the limiting age by witch the child should speak correctly, very similar to what was corcluded in other research on the subject ${ }^{2}$. In a research project us- ing speech disorders on te clinical data ${ }^{1}$, it has been found that only $11.2 \%$ of patients were diagnosed during early childhood before the age of three. It seems therefore that even though it is expected that children speak when they are 18 months old, itis very usual that parents and caregivers only are informed about the diapursis of these disorders should only be after the child is 4 or 5 years old ${ }^{1}$.

When it is suspected that the child has a speech delay, most parents said that first of all the would look for a speech therapist, followed by the pediatrician.

This aspect is highly consistent with the knowledge showed by interviewed subjects, providing most of them have a knowledge compatible with that envisioned in the speech therapy field: first meaningful words should be spoken by 18 months of life and up to 48 months, in general, child speech must be similar to adult standard ${ }^{4}$.

In any case, the literature also shows that the clinical performance in evaluation, comorbility prevention and rehabilitation, considering that some of these assignments are not unique to the speech therapist $2,5,8,9$. Parents emphasize speech therapist performance abilities in early childhood for speech,

** You dray make several choices. 
hearing, reading, writing, deglutition, voice, and breathing evaluation and/or rehabilitation, in line with the literature.

The age of two is agreed by interviewed parents as the ideal age for the correction of speech performance in early childhood, when necessary. This datum differs from that givn in previous research where it is staded that the speech therapist can act at any age?.

Anyway, this study finding is based on interviewed population specificity, in which all the children already have a kind of oral communication and the most elicited problems referring communication disorders are related to oral communication, whose extreme signals are more visible exactly around 18 to 24 months of life. Besides that these findings also support the most current vision that the speech therapist role is to threat and detect disorders, being the prevention an aspect not very known and spread to the overall population; as are not very known the most effective mechanisms for childhood language disorders prevention.

With regard to the seek for care, speech therapy guidance and/or evaluation for the child, we couldn't find researches mentioning this issue so that it was not possible to compare findings and literature.

The hearing is constituted by a prerequisite for language acquisition and development; hearing and language are correlated and interdependent functions10. Most of parents don't know or have a vague knowledge about their children audiological aspects, like etiology data, deafness diagnose, knowledge about hearing AIDS $^{5}$.

In another study about the hearing importance for parents or caregivers, it was identified that $55.1 \%$ of subjects pointed only the ability of hearing as relevant5; relatives in general didn't refer hearing as important for children overall development5. In the presented study, the parents demonstrated a broadest and more consistent knowledge with what is nowadays advocated by speech therapy for the hearing importance in the child's life, as well as the different consequences resulting from hearing difficulties in the first childhood.

Considering baby bottles and nursing nipple, most of interviewed ones consider their use responsible for speech disorders, myofunctional disorders and emotional difficulties.

Their use for a long period of time can be explained through cultural aspects and by their spread into the media11, and parents lack of awareness of the harm caused by baby bottles ${ }^{12}$.

A great part of healthcare providers, lay people and mothers believe nursing nipples are harmless or even necessary and beneficial for the child development, having an indifferent or permissive attitude ${ }^{13}$. Some researches ${ }^{14,15}$ shows that the use of nursing nipples is inversely proportional to the exclusive breastfeeding ${ }^{14}$, and that breastfeeding (and consequently baby bottles deprivation) is inversely proportional to negative oral habits ocurrence ${ }^{15}$. However, the nursing nipple, when necessary for reaching emotional stability, must be used rationally, since harmful effects severity is related to duration (period of use), frequency (number of times per day) and intensity (each suction duration and involved muscles activity) used, and may determine dental malocclusion, poor tongue posture and articulatory problems ${ }^{16}$.

The family decides whether the nurse nipple will be used or not. It's about the healthcare providers to inform the parents about nurse nipple pros and cons so they can take a informed decision ${ }^{17}$.

There was no significant relationship between parents knowledge about the use of nurse nipples and baby bottles and their education level. This was not observed in previous studies where there was a relationship between the maternal low education level and the use of nurse nipples ${ }^{18}$.

This study findings refer to parents' perception about phonoaudiological disorders, more specifically oral language disorders and hearing disorders during first childhood, considering there was no parents' perception comparison with an evaluation about their children phonoaudiological health condition. Like this it was not possible to evaluate the knowledge accuracy demonstrated by interviewed people, in other words, if the information provided is consistent with their children reality.

By the other hand, this study conclusions contribute for identifying parents' perception about phonoaudiological disorders in first childhood, compounding a consistent framework so that more specific approaches are conducted for these populations, whether in view of the early identification of these disorders in these population or in the guidance of other professionals which act more directly with these children so these also early identify phonoaudiological disorders and make appropriate referrals when relevant.

Based on studies previously mentioned ${ }^{1-7}$, we can note there is a lack of researches addressing people's knowledge about the possibility of early identification and communication disorders rehabilitation, whether healthcare providers or lay people. These studies are relevant for spreading these disorders' evaluation possibilities, diagnose and treatment, in a way that the community itself (whether of lay people or of related areas professionals) can contribute with the identification of existing demands for specialized trial (by a speech therapist). Besides knowledge enlargement about the potential impacts of the work developed by the speech therapist can concur for a greater visibility to the profession.

Finally parents' knowledge are merging with the observed in the present day concerning comorbities occurrence associated to hearing difficulties, language acquisition and development in first childhood. There is a directly proportional relation between the parents' knowledge level, their education and how they see the phonoaudiological disorders measurable symptoms, and speech therapist to be consulted in case of speech delay suspect and of these professional intervention possibilities identification when the child is in the first childhood, if necessary. 


\section{REFERENCES}

1. Hage SRV, Faiad LNV. Perfil de pacientes com alteração de linguagem atendidos na clínica de diagnóstico dos distúrbios da comunicação Universidade de São Paulo - campus Bauru. Rev. CEFAC 2005; 7(4): 433-440.

2. Bitar ML, Latorre MRDO, Viude A, Takahashi LN, Silva VPP. Caracterização da saúde de crianças atendidas em creches e prevenção dos distúrbios de comunicação. Rev. Saúde Públ. 1994; 28(1): 46-58.

3. Schirmer CR, Fontoura DR, Nunes ML. Distúrbios da aquisição da linguagem e da aprendizagem. J. Pediatr. (Rio J.) 2004; 80(2 Supl): 95-103.

4. Goulart BNG, Chiari BM. Prevalência de Desordens de Fala em Escolares e Fatores Associados. Rev. Saúde Públ. 2007; 41(5): 726-731.

5. Silva VVC, Padovani CA, Bomfim FR. Conhecimento dos pais de crianças surdas sobre a reabilitação auditiva: uma experiência em Salvador. Rev. Baiana Saúde Pública 2007; 31(1): 7-18.

6. Lemos MES, Barros CGC, Amorim RHC. Representações familiares sobre as alterações no desenvolvimento da linguagem de seus filhos. Distúrb. comun. 2006; 18(3): 323-333.

7. Pimentel $A G L$, Herrera $S A L$, Duarte TF. Conhecimento que acompanhantes de pacientes de uma clínica-escola de Fonoaudiologia tem sobre a atuação fonoaudiológica. Rev. Soc. Bras. Fonoaudiol. 2010; 15(1): 40-6.

8. Goulart BNG, Chiari BM. Avaliação Clínica Fonoaudiológica, Integralidade e Humanização: perspectivas gerais e contribuições para reflexão. Rev. Soe. bras. fonoaudiol. 2007; 12 (4): 335-340.
9. Lipay MS, Almeida EC. A fonoaudiologia e sua inserção na saúde pública. Rev. ciênc. méd., (Campinas) 2007; 6(1): 31-41.

10. Chiari BM, Goulart BNG, Nishihata R et al. Perda auditiva sensorioneural unilateral e distúrbios da comunicação. Rev. bras. crescimento desenvolv. hum. 2012; 22(1): 81-84.

11. Carvalho GD. A amamentação sob a visão funcional e clínica da odontologia. Rev. Secretarias de Saúde 1995; 10(1): 12-13.

12. Trawitzki LVV, Lima WTA, Melchior MO, Grechi $\mathrm{TH}$, Valera FCP. Aleitamento e hábitos orais deletérios em respiradores orais e nasais. Rev Bras Otorrinolaringol 2005; 71(6):747-751.

13. Lamounier JA. O efeito de bicos e chupetas no aleitamento materno. J. Pediatr. (Rio J.) 2003; 79(4): 284-286.

14. Legovic $M$, Ostric $L$. The effects of feeding methods on the growth of the jaws in infants. In: Neiva FCB, Cattoni DM, Ramos JLA, Issler H. Desmame precoce: implicações para o desenvolvimento motor-oral. J. Pediatr. (Rio J.) 2003; 79 (1): 07- 15.

15. Serra-Negra JMC, Pordeus IA, Rocha JF. Estudo da associação entre aleitamento, hábitos bucais e maloclusões. In: Neiva FCB, Cattoni DM, Ramos JLA, Issler $\mathrm{H}$. Desmame precoce: implicações para o desenvolvimento motor-oral. J. Pediatr. (Rio J.) 2003; 79 (1): 07-12.

16. Silva EL. Hábitos bucais deletérios. Rev. Para. Med. 2006; 20: 47-50.17. Castilho SD, Rocha MAM. Uso de chupeta: história e visão multidisciplinar. J. Pediatr. (Rio J.) 2009; 85(6): 480-489.

18. Tomasi E, Victora CG, Post PR, Olinto MTA. Béhague $D$. Uso de chupeta em crianças: contaminação fecal e associação com diarréia. In: Lamounier JA. O efeito de bicos e chupetas no aleitamento materno. J. Pediatr. (Rio J.) 2003; 79(4): 284-286. 